\title{
Critical care management of a patient with generalized arterial calcification of infancy
}

\author{
Lorenzo Galletti ${ }^{1}$, Ezio Bonanomi², Silviya Khemio Arnes ${ }^{3}$, Vasyl Lazoryshynetz ${ }^{3}$
}

\author{
${ }^{1}$ Cardiosurgery department of Pediatric and Congenital Cardiopathies, \\ Hospital Papa Giovanni XXIII (Bergamo, Italy) \\ ${ }^{2}$ Department of Pediatric Intensive Care, Hospital Papa Giovanni XXIII (Bergamo, Italy) \\ ${ }^{3}$ Department of Pediatric Cardiac Surgery, National Institute of Cardiovascular Surgery (Kyiv, Ukraine)
}

\begin{abstract}
: we describe the case of an infant hospitalized in our pediatric intensive care unit with suspected miocarditis. The diagnosis of generalized arterial calcification of infancy (GACI) was confirmed after genetic analysis, the patient was 6 days on extracorporeal membrane oxygenation and died after a failed attempt of endovascular stent placement on $19^{\text {th }}$ day of hospitalization. This paper also contains a review of the literature including new insights into genetic and molecular mechanisms concerning the development of GACI, describe the pathophysiology of the disease and discuss the recent possible ways of treatment and management of GACI.
\end{abstract}

Key words: generalize arterial calcification of infancy; congestive heart failure; calcifications; periarticular calcifications; hypertension; infant; neonate; genetics.

Generalized arterial calcification of infancy (GACI) is a rare and severe autosomal recessive disorder, reported to date in $~ 200$ individuals. ${ }^{3,13}$ GACI is characterized by calcification of the internal elastic lamina of large and medium-sized arteries and marked myointimal proliferation leading to arterial stenoses, as well as by foci of periarticular calcification. ${ }^{13}$ The main clinical manifestations of the disease are respiratory distress, hypertension and congestive heart failure with or without myocardial ischemia. ${ }^{9}$ The association of GACI with persistent pulmonary hypertension (PPHN) is rare. ${ }^{5,14}$ Additional findings can include extravascular calcifications, typical skin and retinal manifestations of pseudoxanthoma elasticum, hearing loss, and development of rickets after infancy. ${ }^{6,11}$ GACI is often fatal within the first 6 month of life because of myocardial ischemia resulting in refractory heart failure.2,11,13

Pathophysiology. The pathophysiology of the disease has been proven to be the result of unregulated excessive deposition of calcium phosphate (hydroxyapatite) crystals in and around the internal elastic lamina resulting in diffuse arterial calcification with fibrointimal hyperplasia causing luminal narrowing. $1,6,7,8$

Antenatally the dystrophic calcification results in decreased vessel compliance and hypertension leading to cardiac failure and hypertrophy of the chambers. Fetal heart failure results in polyhydramnios, fetal hydrops and, usually, death during the third trimester. ${ }^{13}$ Heart failure in infancy has been attributed to myocardial ischemia related to stenosis and luminal occlusion of the coronary arteries. ${ }^{8}$ Hypertension is likely due to two mechanisms: increased vascular resistance as a result of vessel wall calcification and widespread luminal narrowing, and also due to elevated serum renin secondary to renal artery stenoses. ${ }^{8}$ Pulmonary hypertension and right heart failure can be caused when the obliterative changes and decrease vessel compliance take place in the pulmonary circulation. ${ }^{8,10}$

Molecular genetics. GACI is a rare genetic disorder with an autosomal recessive pattern of inheritance associated with mutations in ENPP1 (ectonucleotide pyrophosphatase/ phosphodiesterase 1) gene localized on chromosome $6 \mathrm{q} 22$ in a subset of patients. ENPP1 is a cell surface enzyme, is expressed on fibroblasts, osteoblasts and hepatocytes. ${ }^{14}$ ENPP1 generates extracellular inorganic pyrophosphate (PPi), which among other functions includes the regulation of vascular smooth muscle cell differentiation and inhibition of soft tissue calcification. ${ }^{3}$

Extracellular matrix calcification must be tightly regulated, as normal calcium and phosphate concentrations in extracellular fluids are near the saturation point for the deposition of basic calcium phosphate crystals in the form of hydroxyapatite. ${ }^{8,11} \mathrm{PPi}$ inhibits hydroxyapatite crystal deposition. Inorganic pyrophosphate is produced by a variety of biochemical reactions and a number of cells appear to channel intracellular PPi to the extracellular matrix. ${ }^{8,11}$

Adecrease in PPi, as a result of mutations in ENPP1 gene, is believed to result in uninhibited calcium deposition in arteries and soft tissues, and it have been linked etiologically to GACI. ${ }^{3,7,12}$ There are other known (ABCC6, NT5E and SLC 20A2) and unknown gene mutations associated with arterial calcification. ${ }^{14}$

Case presentation. An 8-month male infant of $9 \mathrm{~kg}$ 
was admitted to our pediatric intensive care unit with the following cardiovascular symptoms: tachypnea, sweating, feeding intolerance. A myocarditis was suspected. The baby was the second child of a non consanguineous mother, born on 39 week of gestation per vias naturalis. The pregnancy and delivery were normal. Growth and development were according to his age. The anamnesis revealed that the first female child died from generalized arterial calcification of infancy at age of 3 month. An echocardiography at birth was performed, showing normal cardiac structures and normal vascular echogenicity.

On admission a series of physical, laboratory and instrumental examinations were performed. The infant presented the next vital parameters: cardiac frequency 140-150 bpm, arterial pressure 55/30 $\mathrm{mmHg}, \mathrm{SpO}_{2} 99 \%$, temperature $37,7^{\circ}$. During clinical examination a cystic calcification in the left sternoclavicular joint was found.

The chest radiography revealed signs of congestive heart (Figure 1). The echocardiography showed left ventricular dysfunction with dilatation of left atrium and left ventricle, a patent foramen ovale with left-right shunt and severe mitral valve insufficiency, the right heart was normal. During the admission day an episode of bradycardia occurred, the patient required a continuous cardiopulmonary reanimation (CPR) without successful resuscitation, and as an emergency measure it was decided to connect an arteriovenous extracorporeal membrane oxygenation (ECMO). Hemodynamic parameters were restored, but laboratory and instrumental examinations showed ischemic changes in the heart, and in order to improve cardiac function an infusion of levosimendan $(0,2 \mathrm{mcg} / \mathrm{kg} / \mathrm{min})$ for 48 hours was started. At this point the inotropic support consisted of adrenaline $0,03 \mathrm{mcg} / \mathrm{kg} / \mathrm{min}$, milrinone 0,8 $\mathrm{mcg} / \mathrm{kg} / \mathrm{min}$. Additional infusions involved anticoagulation therapy, diuretics, sedation, antibiotic prophylaxis,

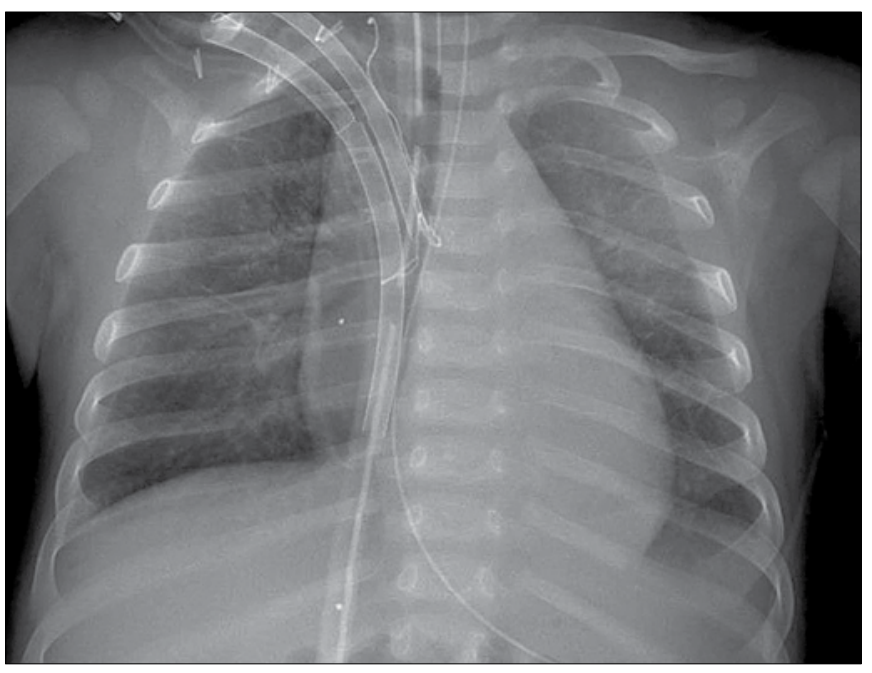

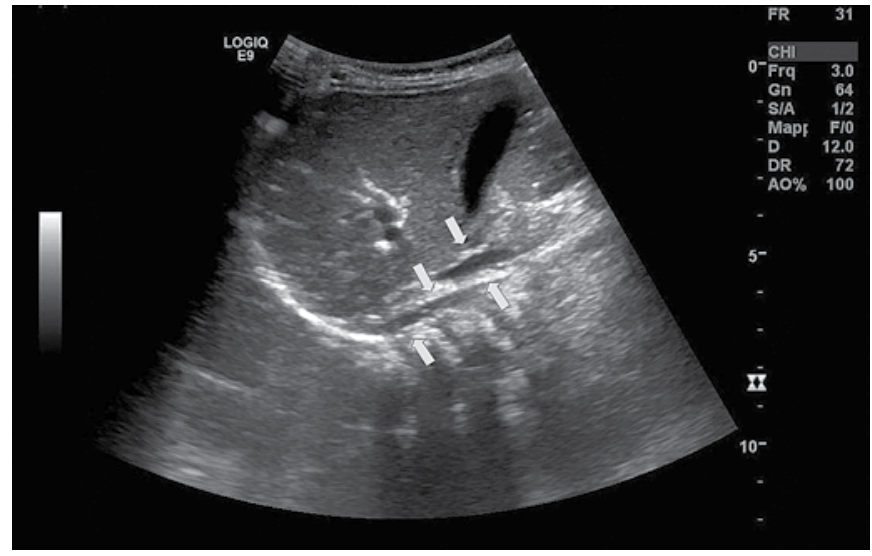

Fig. 2. The ultrasound of the abdomen shows increased echogenicity of the abdominal aorta and the celiac trunk

electrolyte solutions. Considering the severity of the patient state, bisphosphonates were introduced in the treatment. Transfusion of blood components was applied according to standard protocols.

\section{Laboratory results at admission.}

Metabolic acidosis (BE-9) with elevated lactate levels ( $3 \mathrm{mmol} / \mathrm{l}$ ) on the admission day. High levels of calcium $22,5 \mathrm{mg} / \mathrm{dl}$, inorganic phosphate $64,7 \mathrm{mg} / \mathrm{dl}$. Phosphate/ creatinine rate $3,80 \mathrm{mg} / \mathrm{mg}$.

Insufficient levels of 25,OH vitamin D $21,8 \mathrm{ng} / \mathrm{ml}$. Increased levels of parathormone $119 \mathrm{pg} / \mathrm{ml}$.

Increased natriuretic peptide $1167 \mathrm{ng} / \mathrm{l}$, increased D-dimer $6812 \mathrm{ng} / \mathrm{ml}$. Elevated levels of troponin I, aspartate aminotransferase, lactate dehydrogenase, creatinine kinase, myoglobin.

\section{Instrumental examinations.}

Electrocardiography showed ischemic changes. The ultrasound of the abdomen showed an calcifications of abdominal aorta and celiac trunk (Figure 2). A coronarography revealed an occlusion of the right coronary artery and a multiple occlusions of the left coronary artery (Figure 3). A CT scan of the abdomen showed a significant calcification of the celiac trunk, in particular of the hepatic artery, and the superior mesenteric artery, as well as dot calcifications of the left renal artery.

\section{Genetical analysis}

The genetical analysis showed recessive mutations of ENPP1 gene. The variation of p.Leu572Ser was caused by the substitution of the base $\mathrm{T}$ with the $\mathrm{C}$ in the position Chr6 (GRCh37) of the gene ENPP1, which caused the substitution of the amino acid leucine with serine in the position 572 of the protein. This was a rare sequence variation, and the instruments of bioengineering prediction indicated that the change was deleterious for the function of the protein.

After 6 days on ECMO, on a medical council, it was de-

Fig. 1. The chest radiograph shows cardiomegaly 


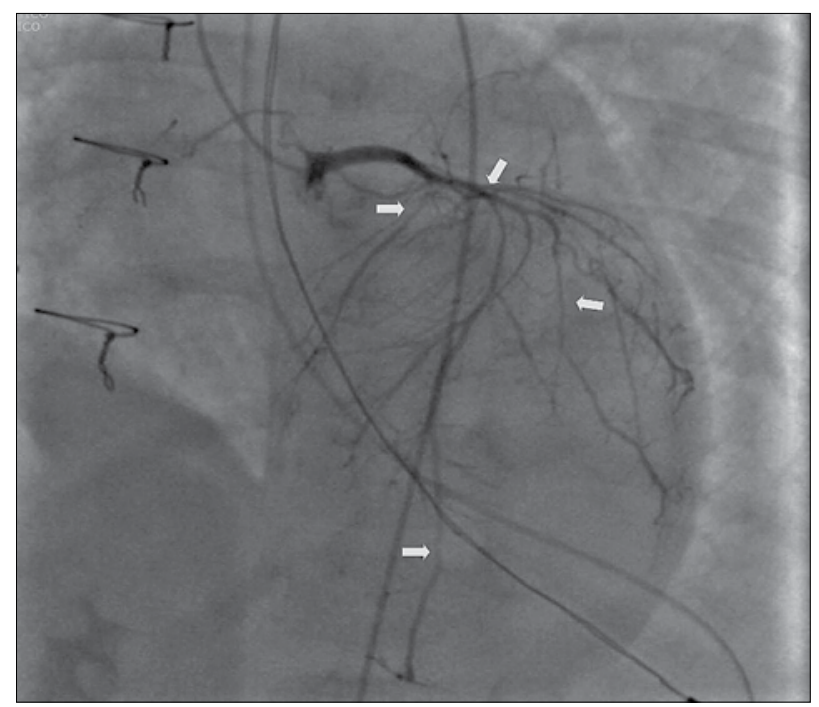

Fig. 3. Coronarography showing luminal irregularities and stenosis of the left coronary artery

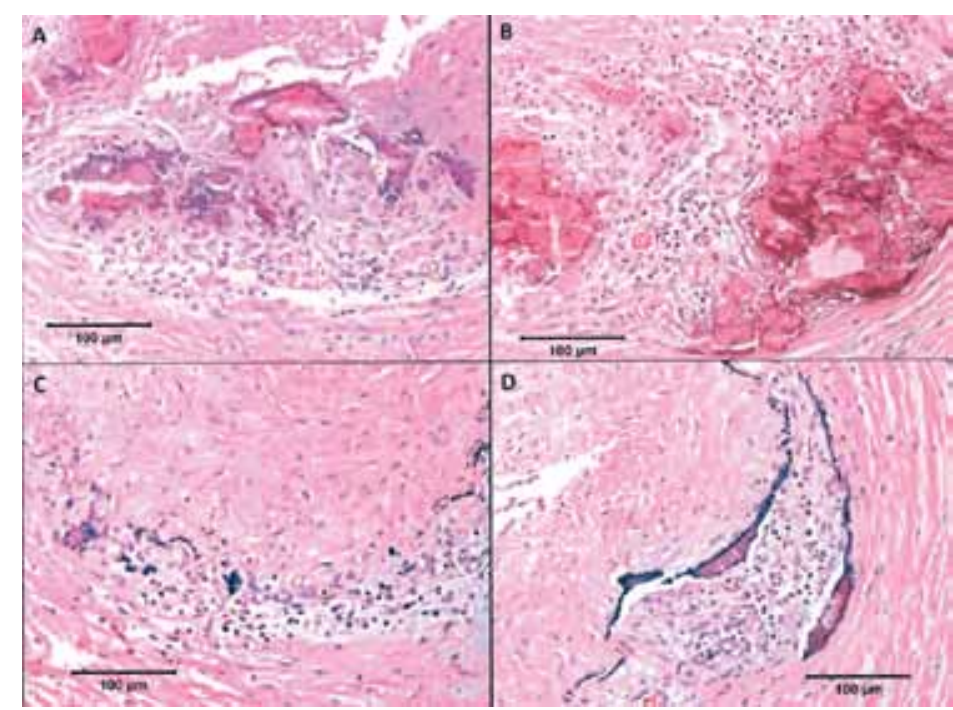

Fig. 4. High power images of coronary arteries showing lymphohistiocytic inflammatory infiltrates in areas of calcification: $A$ - right coronary artery; $B$ - ramus intermedius; $C$ - left anterior descending artery; $D$ - left circumflex artery

cided to wean the patient from the extracorporeal support, considering the absence of surgical solutions for the systemic vascular disease. Inotropic support was escalated previous to removal, the condition of the patient remained stable and the patient was on ventilation with the next vital parameters: cardiac frequency $145 \mathrm{bpm}$, arterial pressure $75 / 45 \mathrm{mmHg}$, $\mathrm{SpO}_{2} 100 \%$, NIRS $78 / 80$. On the $12^{\text {th }}$ day of hospitalization, and 6 days after ECMO removal, a severe decompensation of cardiac function occurred with elevated lactate

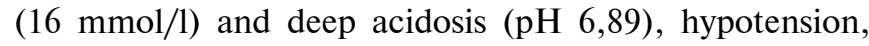
tachycardia, oliguria and symptoms of pulmonary edema. During the following days the condition of the patient worsened, inotropic support was increased, ventilatory parameters were reinforced, enteral nutrition was suspended. A septic shock was suspected, and empiric antibiotic therapy was adjusted and continuous infusion of noradrenaline $(0,04 \mathrm{mcg} / \mathrm{kg} / \mathrm{min})$ was initiated.

An echo control of cardiac function showed akinetic left ventricle in the septal, lateral and posterior regions, ejection fraction 20-30\%, mild mitral valve insufficiency. A continuous amiodaron infusion was added to the therapy considering the persistent tachyarrhytmia. As an extreme measure another coronarography was planned. The attempt to dilate the anterior descending coronary artery failed. On the $19^{\text {th }}$ day of intensive care treatment, the cardiac insufficiency led to severe bradycardia and hypotension, the hemodynamic state of the patient was critical, and after continuous and ineffective CPR the patient died.

\section{Postmortem histologic examination}

A histologic examination of the coronary arteries revealed diffuse calcification of epicardial coronary arteries. Histologic sections showed severe luminal narrowing of all epicardial coronary arteries associated with calcification of internal elastic lamina, extensive areas of medial destruction with chronic inflammation including lymphocytes and macrophages, and marked intimal proliferation (figure 4).

Multiple representative sections of the aorta and major branches showed foci of calcification of elastic lamellae, smooth muscle loss with lymphohistiocytic replacement, and variable degrees of intimal proliferation. Changes are mild in the ascending aorta, with only scattered small foci of calcification in the inner third of medial elastic lamellae. Thoracic and abdominal aorta show greater destruction of elastic lamellae and smooth muscle loss, as well as moderate intimal proliferation (Figure 5). Little or no calcification is seen in left and right common carotid arteries, while there is significant calcification, smooth muscle destruction and intimal proliferation in right and left subclavian arteries. Calcification of internal elastic laminae, smooth muscle loss and intimal proliferation are also seen in celiac artery, superior mesenteric artery, renal artery and common iliac arteries.

At autopsy, the gross examination revealed a dull gray granular epicardial surface with prominent coronary arteries, patent foramen ovale, left ventricular dilatation: left ventricular cavity diameter $30 \mathrm{~mm}$, left ventricular free wall thickness $5 \mathrm{~mm}$, ventricular septum thickness $7 \mathrm{~mm}$, right ventricle thickness $3 \mathrm{~mm}$. The endocardial surface of the left ventricle was hypertrabeculated, and there was a circumferential left ventricular subendocardial fibrosis and hyperemia. Histologic sections showed circumferential healed and healing subendocardial and focally transmural infarctions in the left ventricle, and patchy ischemic foci in the right ventricle (Fig. 6). 


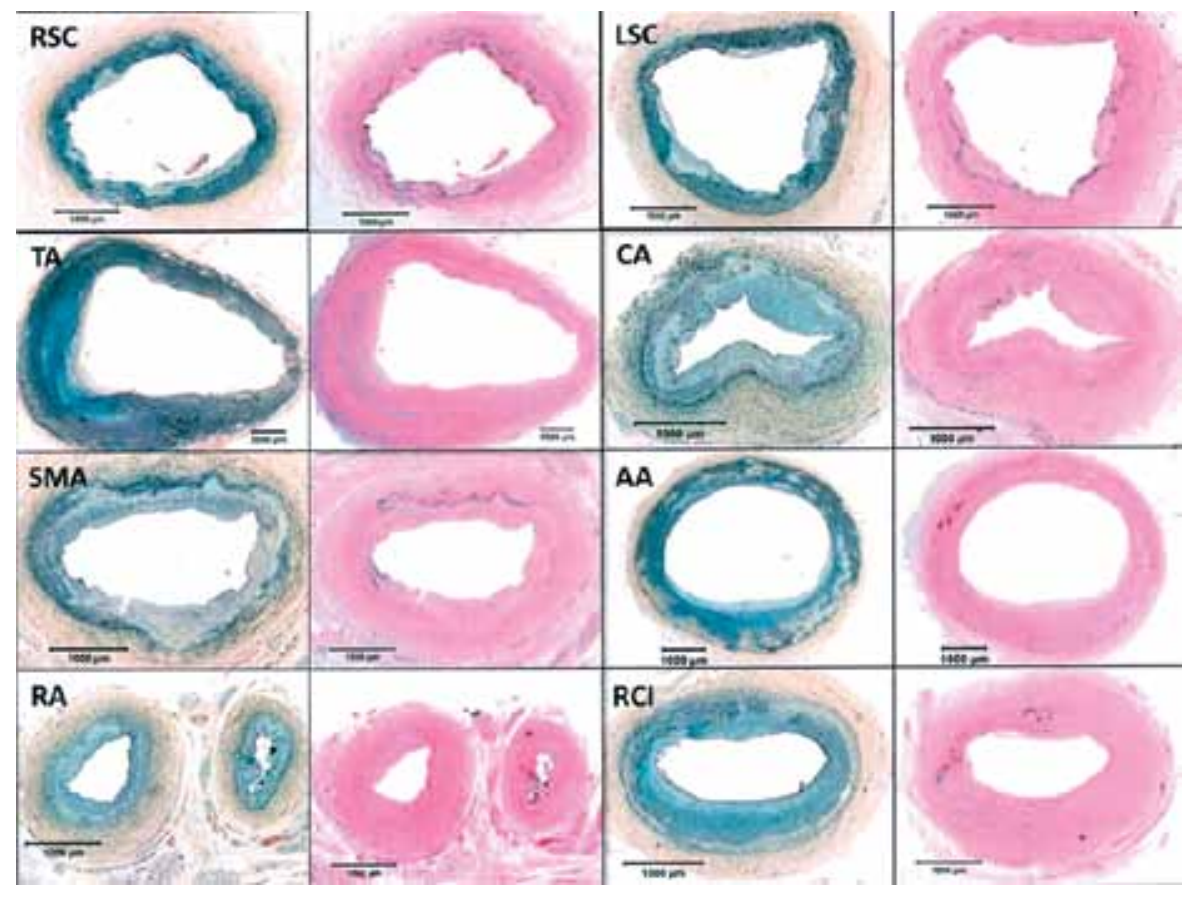

Fig. 5. Representative sections of aorta and major branches: RSC (right subclavian artery), LSC (left subclavian artery), TA (thoracic aorta), CA (celiac artery), SMA (superior mesenteric artery), $A A$ (abdominal aorta), RA (renal artery), $R C I$ (right common iliac)

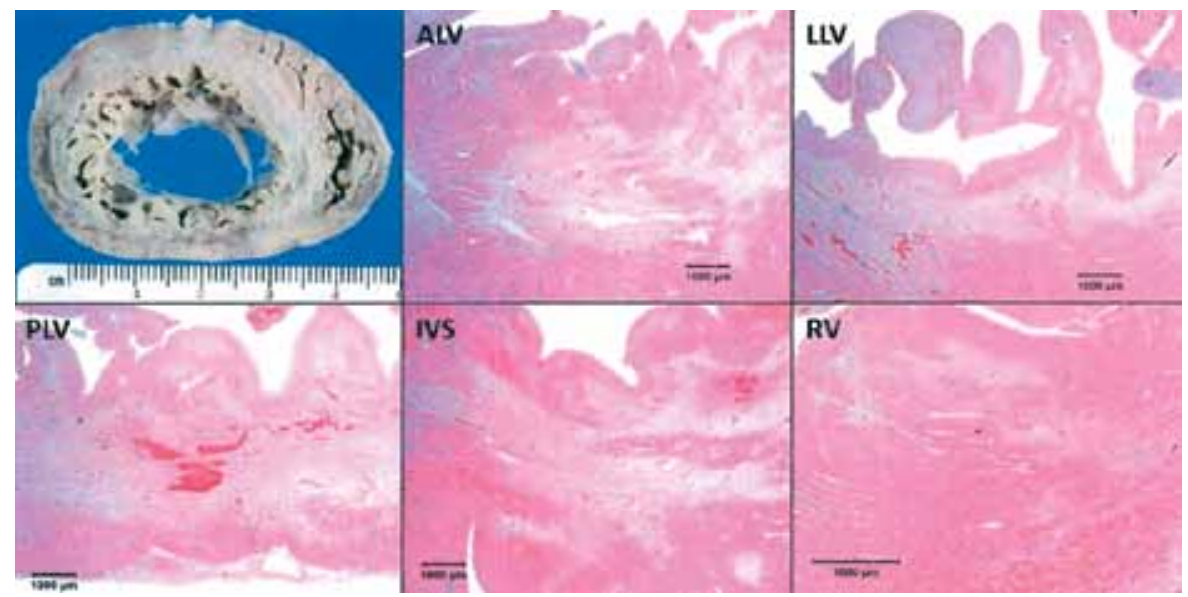

Fig. 6. Gross and histologic images of heart showing healed and healing subendocardial and focally transmural infarctions

ders, normal serum calcium and phosphorous panel and a positive family history suggest GACI. ${ }^{14}$ The diagnosis is established in a patient with cardiovascular symptoms associated with: widespread arterial calcification on imaging; identification of biallelic pathogenic variants during molecular testing in ENPP1 or ABCC6; typical histologic findings on arterial biopsy. ${ }^{6}$ The gold standard for diagnosis is arterial biopsy. ${ }^{14}$ GACI may be under recognized, and the diagnosis should be suspected in patients with multiple arterial stenoses even in the absence of radiographic calcification. ${ }^{4}$ On many occasions, family history reveals consanguinity. ${ }^{8,13}$

Clinical manifestations are related to vasoocclusive disease of multiple organs. ${ }^{14}$ GACI has 2 possible clinical presentations: the $1^{\text {st }}$ in utero or shortly after birth, and the $2^{\text {nd }}$ at approximately 3 or 4 month of age, with most of survivors falling into the first group. ${ }^{3}$ Initial signs of the disease may occur prenatally with fetal distress, polyhydramnios and pericardial effusion reported most frequently. ${ }^{13}$

During neonatal period the presenting feature in over $50 \%$ of cases is respiratory distress, followed by feeding intolerance and poor weigh gain. When the age of presentation is 3 or 4 month, the clinical manifestations usually include respiratory distress, cyanosis, feeding intolerance, heart failure, vomiting and irritability. ${ }^{3}$ Patients show symptoms of progressive heart failure, with tachypnea, tachycardia, lethargy, pallor. Other rarer symptoms are: hypertension, seizure, syncope and abdominal ileus secondary to visceral infarction. ${ }^{8}$ Periarticular calcifications are thought to be another stigma of GACI , they are more frequently observed around the hip, ankle, wrist or shoulder. ${ }^{3}$

The final diagnosis based on histological findings was: Idiopathic arterial calcification of infancy involving coronary arteries, aorta and major systemic aortic branches including right and left subclavian arteries, celiac artery, superior mesenteric artery, renal arteries and common iliac arteries. Circumferential healed and healing subendocardial and focally transmural myocardial infarctions.

Discussion. GACI is an exclusively rare and severe disease. Absence of other infantile arterial calcification disor-
Despite the recent link between the ENPP1 gene and GACI, it is unclear what factors determine the severity of disease or prognosis of affected patients. ${ }^{11,13}$ This is supported by the observation of a sibling pair with an identical ENPP1 mutation but different clinical manifestations. ${ }^{2}$

Other conditions capable of causing generalized arterial calcifications are: metastatic calcifications secondary to advanced renal disease; arterial calcifications associated with anomalies of the heart or great vessels; hypervitaminosis D; 
primary or secondary hyperparathyroidism, ${ }^{8,9}$ SingletonMerten syndrome. ${ }^{3}$

Within the last few years, bisphosphonates, which function in part as synthetic nonhydrolyzeable analogues of PPi, have been reported to have varying degrees of success in the treatment of GACI. ${ }^{13}$ This is a group of simple compounds containing phosphate-carbon-phosphate bonds that act by inhibiting the precipitation of several calcium salts in vitro as well as by blocking the conversion of amorphous calcium phosphate into crystalline hydroxyapatite. They are also known to prevent ectopic mineralization and bone resorption in vivo. ${ }^{9}$ Long-term survival has also been reported in patients receiving no specific antimineralization therapy, suggesting that spontaneous resolution of calcifications may also occur. ${ }^{15}$

Conclusions. GACI is a rare disorder, it should be suspected whenever a neonate or infant presents with unexplainable cardiac failure, calcification of vessels on X-ray or echocardiography or presence of concentric hypertrophic ventricles.

Currently, there is no definitive therapy, although there have been some reports of clinical improvement with bisphosphonates therapy, but results are inconsistent and overall effectiveness remains unknown. Prompt diagnosis and referral for cardiac transplantation may be the best approach to management.

\section{Abbreviations}

ABCC6: ATP-binding cassette (ABC transporters);

CPR: cardiopulmonary resuscitation;

ECMO: extracorporeal membrane oxygenation;

Echo: Echocardiography;

ENPP1: ectonucleotide pyrophosphatase/phosphodiesterase 1 ;

$\mathrm{FiO}_{2}$ : fraction of inspired oxygen;

NT5E: 5'-nucleotidase, ecto (CD73);

NIRS: near-infrared spectroscopy;

PPi: inorganic pyrophosphate;

SLC 20A2: SL solute carrier family 20 (phosphate transporter);

$\mathrm{SpO}_{2}$ : peripheral oxygen saturation;

\section{Conflict of interest}

The authors declared no conflict of interest.

\section{Authors' contributions}

LG obtained consent for publication, EB reviewed and edited the manuscript, and approved the final revised manuscript as submitted. SK and AP provided patient care, helped in the literature search, reviewed the manuscript and approved the final revised manuscript as submitted. SK has written the first and revised draft of the manuscript, provided patient care in the NICU, approved the final revised manuscript as submitted. AP helped in the literature search, reviewed and revise the first draft, and approved the final revised manuscript as submitted.

\section{Acknowledgments}

We thank the parents of our patient for their cooperation and support, and for providing consent for publication. We also thank hospital nurses for their assistance with the management of this patient.

\section{References}

1. Aldandan J., Almoghannam A., Alkhars A., Shaath G. Idiopathic infantile arterial calcification: a case report. J. Pediatr. Child Care 3 (1): 3, 2017.

2. Cheng K-S, Chen M-R, Ruf N, Lin S-P, Rutsch F. Generalized arterial calcification of infancy: different clinical courses in two affected siblings. Am J Med Genet A. 136:210-3, 2005.

3. Chong CR, Hutchins GM. Idiopathic infantile arterial calcification: the spectrum of clinical presentations. Pediatr Dev Pathol. 11:405-15, 2008.

4. Dlamini N, Splitt M, Durkan A, Siddiqui A, Padayachee S, Hobbins S, Rutsch F, Wraige E. Generalized arterial calcification of infancy: phenotypic spectrum among three siblings including one case without obvious arterial calcifications. Am J Med Genet A. 149A:456-60, 2009.

5. Farquhar J, Makhseed N, Sargent M, Taylor G, Osiovich H. Idiopathic infantile arterial calcification and persistent pulmonary hypertension. Am J Perinatol. 22:121-5, 2005.

6. Ferreira C, Ziegler S, Gahl W. Generalized Arterial Calcification of Infancy. 2014 Nov 13. In: Pagon RA, Adam MP, Ardinger HH, et al., editors. GeneReviews ${ }^{\circledR}$ Seattle (WA): University of Washington, Seattle; 1993-2017. World Wide Web URL: https://www.ncbi.nlm.nih.gov/books/ NBK253403/

7. Gengaimuthu Karthikeyan Generalized arterial calcification of infancy. J. Pediatr. 162: 1074, 2013.

8. Glatz A.C., Pawel B.R., Hsu D.T., Weinberg P., Chrisant M.R.K. Idiopathic infantile arterial calcification: two case reports, a review of literature and a role for cardiac transplantation. Pediatr. Transplantation 10: 225-233, 2006.

9. Maayan, C., Peleg, O., Eyal, F., Mogle, P., Rosenmann, E., Bar Ziv, J. Idiopathic infantile arterial calcification: a case report and review of the literature. Europ. J. Pediat. 142: 211-215, 1984.

10. 10.Morton R. Idiopathic arterial calcification in infancy. Histopathology. 2:423-32, 1978.

11. Online Mendelian Inheritance in Man, OMIM ${ }^{\circledR}$. Johns Hopkins University, Baltimore, MD. MIM Number: 208000: 10/14/2016. World Wide Web URL: https://omim. org/entry $/ 208000$ ? search $=208000$ \&highlight $=208000$

12. Ramjan KA, Roscioli T, Rutsch F, Sillence D, Munns CFJ. Generalized arterial calcification of infancy: treatment with bisphosphonates. Nat Clin Pract Endocrinol Metab. 5:167-72, 2005.

13. Rutsch, F., Boyer, P., Nitschke, Y., Ruf, N., LorenzDepierieux, B., Wittkampf, T., Weissen-Plenz, G., Fischer, R.-J., Mughal, Z., Gregory, J. W., Davies, J. H., Loirat, C., Strom, T. M., Schnabel, D., Nurnberg, P., Terkeltaub, R., GACI Study Group. Hypophosphatemia, hyperphosphaturia, and bisphosphonate treatment are associated with survival beyond infancy in generalized 
arterial calcification of infancy. Circ. Cardiovasc. Genet. 1: 133140, 2008.

14. Shaireen H., Howlett A., Amin H., Yusuf K., Kamaluddeen M., Lodha A. The mystery of persistent pulmonary hypertension: an idiopathic infantile arterial calcification. BMC Pediatrics 13: 107, 2013.
15. Sholler G., Yu J., Bale P., Hawker R., Celermajer J., Kozlowski K. Generalized arterial calcification of infancy: Three case reports, including spontaneous regression with long term survival. J. Pediatr. 105: 257-260, 1984.

\title{
Ведення пацієнта дитячого віку з генералізованою артеріальною кальцифікацією в умовах інтенсивної терапії
}

\author{
Лоренцо Галлетті ${ }^{1}$, Еціо Бонаномі², Сільвія Хеміо Арнес ${ }^{3}$, Василь Лазоришинець ${ }^{3}$ \\ ${ }^{1}$ Відділення кардіохірургії педіатричних та вроджених кардіопатій, лікарня Рара Giovanni XXIII (Бергамо, Італія) \\ ²Відділення дитячої інтенсивної терапії, лікарня Papa Giovanni XXIII, (Бергамо, Італія) \\ ${ }^{3}$ Відділення дитячої кардіохірургії, Національний інститут серцево-судинної хірургії (Київ, Україна)
}

В роботі описується клінічний випадок 8-місячної дитини, масою тіла 9 кілограмів, з рідкісним захворюванням - генералізованою артеріальною кальцифікацією дитячого віку (ГАКД). У світі наразі нараховується близько 200 клінічних випадків даної патології. ГАКД - це рідкісне аутосомно-рецисивне захворювання, яке характеризується кальцифікацією артерій великого і середнього калібру, що зумовлено міоінтимальною проліферацією внутрішньої еластичної оболонки, фіброзом інтими з подальшим артеріосклерозом, 85\% хворих дітей до 6 місяців життя мають високий ризик смертності від інфаркту міокарда, дихальної та серцевої недостатності, важкої артеріальної гіпертензії.

Дитина була госпіталізована в педіатричне відділення інтенсивної терапії з підозрою на міокардит. Діагноз ГАКД був підтверджений після генетичного аналізу, пацієнт був 6 днів на екстракорпоральній мембранній оксигенації і помер після невдалої спроби встановлення ендоваскулярного стента на 19-й день госпіталізації. Посмертне гістологічне дослідження проводилося в спеціалізованій клініці США. У цій статті наводиться огляд літератури, що включає нові відомості про генетичні та молекулярні механізми розвитку ГАКД, описання патофізіології захворювання і обговорення останніх можливих шляхів лікування та введення пацієнтів з ГАКД, оскільки на даний момент не існує остаточного протоколу лікування даної патології. Швидке діагностування і направлення на трансплантацію серця можуть бути кращим підходом до лікування.

Ключові слова: генералізована артеріальна кальцифікація дитячого віку; застійна серцева недостатність; кальцифікації; периартикулярні кальцифікації; артеріальна гіпертензія; діти молодшого віку; новонароджені; генетичні порушення. 